\title{
Valuing Compromise for the Common Good
}

\section{Citation}

Gutmann, Amy, and Dennis F. Thompson. "Valuing Compromise for the Common Good." Daedalus 142.2 (Spring 2013): 185-198

\section{Published Version}

http://dx.doi.org/10.1162/DAED_a_00212

\section{Permanent link}

http://nrs.harvard.edu/urn-3:HUL.InstRepos:10591657

\section{Terms of Use}

This article was downloaded from Harvard University's DASH repository, and is made available under the terms and conditions applicable to Other Posted Material, as set forth at http:// nrs.harvard.edu/urn-3:HUL.InstRepos:dash.current.terms-of-use\#LAA

\section{Share Your Story}

The Harvard community has made this article openly available.

Please share how this access benefits you. Submit a story.

Accessibility 


\title{
Valuing Compromise for the Common Good
}

\author{
Amy Gutmann \& Dennis Thompson
}

\begin{abstract}
Pursuing the common good in a pluralist democracy is not possible without making compromises. Yet the spirit of compromise is in short supply in contemporary American politics. The permanent campaign has made compromise more difficult to achieve, as the uncompromising mindset suitable for campaigning has come to dominate the task of governing. To begin to make compromise more feasible and the common good more attainable, we need to appreciate the distinctive value of compromise and recognize the misconceptions that stand in its way. A common mistake is to assume that compromise requires finding the common ground on which all can agree. That undermines more realistic efforts to seek classic compromises, in which each party gains by sacrificing something valuable to the other, and together they serve the common good by improving upon the status quo. Institutional reforms are desirable, but they, too, cannot get off the ground without the support of leaders and citizens who learn how and when to adopt a compromising mindset.
\end{abstract}

AMY GUTMANN, a Fellow of the American Academy since 1997, is President of the University of Pennsylvania, where she is also the Christopher H. Browne Distinguished Professor of Political Science.

DENNIS THOMPSON, a Fellow of the American Academy since 1994, is the Alfred North Whitehead Professor of Political Philosophy and Professor of Public Policy at Harvard University.

( "See endnotes for complete contributor biographies.)
Democratic politics should serve the common good, which we understand as the goal of "maintaining conditions and achieving objectives" that benefit all members of society. ${ }^{1}$ The individual components of the common good - such as a robust economy or universal health care - are not necessarily shared by everyone. But the goal is to secure these goods for all, and to maintain a democratic process that is valued by all.

Important as the common good is, it is less frequently invoked by politicians and pundits than is the common ground. Faced with the challenge of bridging polarized partisan divides on pressing issues such as tax reform, health care, and immigration policy, American politicians regularly claim to seek consensus on the common ground. They in effect deny the need to reach compromises that would require them to sacrifice something valuable to their opponents.

Consider this excerpt from a CBS 60 Minutes interview with Representative John Boehner, who

(C) 2013 by Amy Gutmann \& Dennis Thompson 
Valuing was then about to become Speaker of the Compro- House following the Republican success for the in the 2010 congressional elections:

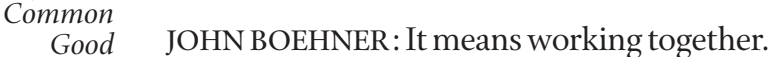

LESLEY STAHL: It also means compromising. $[\ldots]$

BOEHNER: I made clear I am not going to compromise on my principles, nor am I going to compromise...the will of the American people.

STAHL: And you're saying, "I want common ground, but I'm not going to compromise." I don't understand that. I really don't.

BOEHNER: When you say the word "compromise"... a lot of Americans look up and go, "Uh-oh, they're going to sell me out."

[...

STAHL: ... you did compromise [to get all the Bush tax cuts made permanent]?

BOEHNER:... we found common ground.

STAHL: Why won't you say - you're afraid of the word.

BOEHNER: I reject the word. ${ }^{2}$

Consensus on common ground is a lofty goal. That's one reason why politicians never tire of claiming that they are seeking it. "Leaders [are successful] not by attacking their opposition but by finding common ground where principles are shared," former Governor Mitt Romney declared during the Republican primary. ${ }^{3}$ After the president's jobs bill failed in October 2011, Senate Majority Leader Harry Reid still insisted: “we'll be bringing up individual components of this legislation to do our utmost to find commonsense, common-ground, job-creating measures that the Republicans will support."4

All citizens want a better life for themselves and their children; all want security, decent health care, and a good education.
By seeking consensus on these common ground desires, politicians believe they can serve the common good without giving up anything valuable to their political opponents.

Where common ground agreements can be found, they can in fact serve the common good. But they are not the only or even the most productive - way to pursue that goal. The classic compromisewhere all sides gain on balance but also sacrifice something valuable to their opponents - is a more promising route to the common good. This is especially the case in a polarized political environment.

Common ground agreements are morally and politically attractive because they have a principled coherence from all perspectives. They resemble what philosophers call an overlapping consensus. Citizens with fundamentally different moral views may agree on relevant principles, though for distinct reasons drawn from conflicting perspectives. ${ }^{5}$ Analogously, legislators set aside conflicting parts of their perspectives in order to reach a shared agreement. Opposing legislators may disagree on the underlying principles of a common ground deal, but they need not make a principled concession in the content of their agreement.

Consensus on common ground is desirable if it can be found. But the common ground is more barren, its potential for yielding meaningful legislation more limited, than the inspiring rhetoric in its favor might suggest. Yes, a consensus exists among legislators and citizens that the tax system needs to be revised, and that the health care system needs to be reformed. But this general consensus on the need for reform does not translate into a common ground agreement on the particular provisions of either a tax or a health care reform bill. To produce reform legislation, specific terms have to be negotiated, and as is often the case at this 
stage, the common ground turns into fractured terrain.

Another problem with common ground agreements is that trying to find the usually small points of policy convergence is likely to prove less effective in addressing major issues than combining big ideas from the partisans. Describing how they managed to gather a majority on their politically diverse commission on fiscal responsibility, cochairs Alan Simpson and Erskine Bowles emphasized the value of "shared sacrifice" that comes from "bold and big" compromises. "The more comprehensive we made [our proposal], the easier our job became," they said. "The tougher our proposal, the more people came aboard. Commission members were willing to take on their sacred cows and fight special interests - but only if they saw others doing the same and if what they were voting for solved the country's problems." 6

The he most serious problem with the preoccupation with the common ground is that it undermines the pursuit of the more challenging but more promising form of agreement: the classic compromise. In a classic compromise, all sides sacrifice something in order to improve on the status quo from their perspective. The sacrifices accepted in a classic compromise are at least partly determined by the opposing side's will, and they therefore require parties not merely to get less than they want, but also, due to their opponents, to get less than they think they deserve.

Classic compromises differ from common ground and other consensual agreements that are based on an underlying convergence of values (the common ground). These agreements set aside the root disagreement in favor of a consensus on shared values expressed by the agreement itself. The values are held in com- mon. A classic compromise differs in that Amy it expresses an underlying and continu- Gutmann ing conflict of values. Disagreements $\begin{aligned} & \text { Thennis } \\ & \text { Thompon }\end{aligned}$ between the parties are embodied by the compromise. The values internal to the compromise are not all shared.

Classic compromises serve the common good not only by improving on the status quo from the agreeing parties' particular perspectives, but also by contributing to a robust democratic process. The goods in a classic compromise are not all held in common; yet all parties benefit from the compromise and value the process by which it is reached. The agreement itself demands the sacrifice of some goods that each party believes should be, but are not, shared.

In the polarized politics of our time, the prospects for consensual agreements based solely on common ground or containing only common goods are increasingly bleak. Exhortations to seek such agreements and exaltations of their value are misleadingly utopian at best. They divert effort from the pursuit of classic compromises and make them look even more like confused surrenders. As we will explain, compromises by their nature are vulnerable to charges of confusion and surrender. The unfavorable comparisons with common ground agreements only compound this vulnerability.

Yet the classic compromise today offers the best hope for political progress. The major issues in current legislative debates represent deep divisions on fundamental questions about the role of government, the nature of justice, and the liberties, rights, and responsibilities of citizens. The broad issues on which many Americans generally favor legislative compromise taxation, government spending, health care, cost controls, job creation, immigration - are unlikely to be addressed at all if legislators hold out for common ground. 
Valuing So if compromise is to be achieved on Compro- these major issues, we must value agreefor the ments that are less morally coherent and Common less politically appealing than those that Good rest on common ground or an overlapping consensus. The Tax Reform Act of 1986 - the most comprehensive tax-reform legislation in modern American history, passed with bipartisan support under the Reagan presidency - was a classic compromise. It combined some measures (eliminating loopholes that favor the wealthy) that reflected liberal principles and others (lowering the marginal rates on top incomes) that violated those principles. The same measure also created a conflict with conservative principles, but in reverse. The Affordable Care Act of 2010 - the most comprehensive health care reform in recent American history - was also a classic compromise. Though it was forged within a single party, the compromise displayed conspicuous tensions between whether the reform should or should not offer a public option, for example.

Governing a democracy without compromise is impossible. To restrict political agreements to common ground or common goods, especially in a polarized partisan environment, is to privilege the status quo, even when all parties agree that reform is needed. Why, then, is compromise so hard when it is so necessary?

$\mathrm{M}$ uch of the resistance to compromise lies in another necessary part of democracy: campaigning for political office. Increasingly, campaigning is intruding into governing, where it is often counterproductive. The means of winning office are subverting the ends of governing once in office. It is only a slight exaggeration to say that in the United States "every day is election day in the permanent campaign."7 The effects of the continuous campaign along with the distorting influence of media and money that accompanies it encourage a mindset among politicians that rejects compromise.

The resistance to democratic compromise is anchored in an uncompromising mindset, a cluster of attitudes and arguments that encourage principled tenacity (standing on principle) and mutual mistrust (suspecting opponents). This mindset is conducive to campaigning but inimical to governing. Resistance to democratic compromise can be kept in check by a contrary cluster of attitudes and arguments - a compromising mindset - that displays principled prudence (adapting principles) and mutual respect (valuing opponents). It is the mindset better suited for governing because it enables politicians to recognize and embrace opportunities for desirable compromise. When enough politicians adopt it enough of the time, the spirit of compromise prevails and the common good benefits.

The influence of campaigning is not necessarily greater than other factors that interfere with compromise. Compromises are difficult for many reasons, including increased political polarization and the escalating influence of money in democratic politics. But the uncompromising mindset associated with campaigning in particular deserves greater attention than it has received. First of all, unlike ideological polarization, campaigning is a desirable part of any democratic process. It becomes a problem only when it interferes with governing. Second, if compromise is to play its proper role in the democratic process, politicians and citizens need to understand not only the relationship between partisan positions and particular compromises, but also the attitudes and arguments that resist or support compromise in general. Finally, the uncompromising mindset reinforces all the other obstacles to compromise. 
Sharp ideological differences, for example, would present less of an obstacle to compromise were they not compounded by the continual pressures of campaigning that the uncompromising mindset supports. Despite standing tenaciously on the right and left wings of their parties, Senators Orrin Hatch and Ted Kennedy joined together to cosponsor many significant legislative initiatives, including measures to improve health care.

In an era characterized by the permanent campaign, the balance in democratic governing needs to shift toward the compromising mindset and the political compromises that it makes possible. The success of democratic politics depends on how elected leaders govern - and therefore on their attitudes toward compromise. But successful democracy also depends on the attitudes of citizens who elect the leaders. They, too, must grasp the value of compromise.

C ompromise is necessary and desirable in a democracy - most Americans usually agree. But particular compromises are contestable-most Americans usually want to contest them. Within limits, a popular posture in democratic politics is: say yes to compromise, but no to compromises.

When asked about compromise in general, most Americans like the idea. In numerous surveys over the past several decades, large majorities of Americans declared themselves in favor of political compromise in general. Even after the sweeping Democratic victory in the midterm elections in 2006, three-quarters of the public continued to call for compromise. ${ }^{8}$ The 2012 election may or may not have produced a clear mandate for any specific policy, but exit polls strongly suggest that most Americans want politicians to cooperate and compromise to end the gridlock in national politics, at least on some policies.
Of course, there are limits to this recur- Amy ring enthusiasm for political compromise. Gutmann After the strong Republican comeback in \&ennis After the strong Republican comeback in Thompson the 2010 congressional midterm elections, a majority of Americans - a large majority of Republicans and a minority of Democrats-said that they prefer political leaders who stick to their positions without compromising. 9 The favorable attitude toward compromise erodes when the political landscape shifts dramatically, especially when insurgent groups on the left or right gain in popularity and political power. ${ }^{10}$

Just as an electoral victory is typically not a mandate for the specific policies on which the candidates campaigned, so, too, the favorable attitude toward compromise in general does not regularly transfer to majority support for particular compromises. This disconnect between general support and the rejection of compromise on a specific issue - be it immigration, taxation, government spending, the environment, or abortion - is a persistent factor in preventing political progress. In fact, on most issues, "openness to compromise is inversely linked to the importance people place on the issue." 11 People seem to like compromise the most on the issues they care about the least.

There are important limits here, too. Opposition to particular compromises often fades in the face of a crisis. When compromise is a condition of avoiding an imminent public disaster, the vast majority of citizens, from across the political spectrum, support compromise. Six out of ten Americans - including a majority of Republicans, independents, and Democrats - wanted the debt supercommittee to compromise, even if they expected to disagree with its recommendations. ${ }^{12}$ Faced with the possibility of a government default in July 2011, even a large majority of Tea Party supporters said Republicans in Congress should compro- 
Valuing mise in order to come to an agreement

Compro- with Democrats to raise the debt ceiling.

forthe When presented with the choice of

Common whether an agreement should include

Good only spending cuts, tax increases, or a combination of both, two thirds of the Tea Party supporters said that it should include a combination of spending cuts and tax increases. ${ }^{13}$ Strong public support for compromise on governmental revenue increases and spending cuts rose again in the face of the "fiscal cliff"- the massive across-the-board federal tax rate increases and defense and entitlement cuts that were threatened to take effect in January 2013.

But once the immediate threat is averted, the critics of the compromise come out in full force, especially when a compromise is reached through an acrimonious process. The debt ceiling agreement in August 2011 was followed by harsh, principled criticism from both sides of the aisle. Similarly, the compromise to avoid the fiscal cliff, brokered by Vice President Biden and Senate Majority Leader McConnell in the waning hours of 2012, was immediately met with intense criticism of both the content of the agreement and the tactics of the negotiators-despite consensus on the need to compromise and the overwhelming Senate vote in favor of the agreement.

Public ambivalence toward political compromise is not unique to Americans who respond to surveys. It reflects the inevitable tension between seeing the need to compromise to make political progress and appreciating the loss of something valuable in agreeing to a compromise.

Political philosophers share a similar ambivalence toward compromise. Edmund Burke, the eighteenth-century conservative thinker and British statesman, declared that "all government, indeed every human benefit and enjoyment, every virtue, and every prudent act, is founded on compromise and barter."14 But as a politician, he famously refused to compromise with his constituents when their will contradicted his judgment. ${ }^{15}$ John Stuart Mill's contemporaries knew the nineteenth-century liberal theorist as an uncompromising radical. But when elected to Parliament, Mill was quite willing to make deals and support concessions to achieve even relatively modest gains. ${ }^{16}$

It might seem, then, that conservatives favor compromise in principle but not in practice, whereas liberals oppose compromise in principle but accept it in practice. But consider the Pew Center's interpretation of its 2007 survey on attitudes toward compromise: "Democrats tend to favor compromise in principle, but not in practice, while Republicans favor compromise in practice, but not in principle." 17 This is precisely the reverse of the Burke/Mill contrast.

The more plausible interpretation is that attitudes toward compromise are not inherent in either ideology or party. Both liberals and conservatives, Democrats and Republicans, can favor compromise in principle while resisting it in practice - and vice versa. In the modern welfare state, even partisans who want less government must legislate to get it, and often that requires compromise. Attitudes toward compromise depend much more on the relative power of the parties at a particular time, the specific issues in question, and the mindsets of the individuals making the judgments.

What is consistent, however, is the persistent disconnect between the attitudes toward compromise in general and the inclinations to make particular compromises. Nothing is more common in political negotiation than praise for the idea of compromise coupled with resistance to realize it. Resistance to specific political compromises prevents the value of com- 
promise in democratic politics from being appreciated. Politicians and citizens tend to discount the general value of compromise when they come to make decisions about particular compromises. To give compromise its due, we need to connect its general value to decisions about particular compromises, and then empower this value to influence negotiations.

W hy should we be concerned that contemporary American politics makes compromise so difficult? After all, some compromises are undesirable, and politicians should sometimes stand resolutely on their principles and oppose legislation that violates those principles. The chief reason to be concerned is that the greater the resistance to compromise, the greater the bias in favor of the status quo.

Privileging the status quo does not mean that nothing changes. It simply means that politicians allow outside forces - the market, expiring agreements, social movements - to control the change. The status quo includes both the current state of affairs and the state that results from political inaction. In the deeply divided politics of 2011, rejecting congressional compromise on raising the debt ceiling would not have left the economy unchanged. Similarly, after the 2012 election, rejecting compromise on tax increases and spending cuts would have allowed economic changes that few wished to see. A status quo bias in politics can result in stasis; it can also produce unintended and undesirable change.

The status quo offers no assurance even of stability, let alone of political progress by any standard. The first value of compromise in practice is that it enables improvements in the existing and ongoing state of affairs. Democratic politics, which represents conflicting points of view, cannot produce change without some mutual accommodation. Without compromise Amy on health care, taxation, and other major Gutmann issues, the status quo prevails, even when Thompson it preserves a policy that does not serve the common good, or produces consequences that create a major crisis.

The key question to ask of any compromise: does the proposal (or any feasible alternative) represent an improvement over the status quo? This question in effect brings the general value of compromise to bear on the decision about a particular compromise. Although compromises are typically seen as, and often are, the products of unprincipled bargaining and reinforcements of the prevailing balance of power, they are also the primary-and often the only-means by which democratic politics can improve on the status quo.

In some cases, the status quo may be preferable to any of the proposed alternatives. Some political scientists have observed that legislative inertia induced by resistance to compromise may not be a problem when voters do not want Congress to act-for example, during the period of large budget surpluses in the late 1990s. But they also recognize that it becomes a serious problem when voters "believe the government should take some action to alleviate a problem." 18

There can also be reasonable disagreement about whether a particular compromise actually is an improvement over the current state of affairs. Opponents of a health care compromise, for example, might agree that it would improve on the current system, but might also believe that accepting the compromise will prevent an even more desirable reform in the future. Or opponents may think that accepting the compromise now will lead to bigger government in the future, which they count as a worse outcome on balance than what they regard as only a modest improvement in the health care 
Valuing system. Admittedly, there may be good Compro- reasons for opposing a particular comfor the promise, but they do not support a genCommon eral resistance to compromise. They do Good not create the presumption against compromise that animates the uncompromising mindset and that dominates contemporary American politics.

General resistance to compromise presumes that the status quo is always preferable to compromise, or that it is always a mistake to yield something to your political adversaries, even when they are willing to yield something to you. Privileging the status quo in this way is not consistent with either a principled liberal or a principled conservative political perspective. Liberals do not always favor the change that compromise can bring, and conservatives do not always oppose it. The same holds for moderates, libertarians, socialists, and other advocates of principled political ideologies. The value of a compromise should be weighed against whether the new policies advance both sides' principles compared with what the status quo produces.

Resistance to compromise is often rooted in the fact that the costs of not compromising are never equal for all parties. The costs of refusing compromise depend on the difference between what credibly can be achieved through compromise and what the status quo offers. This perceived difference will vary according to the priorities of the parties to the compromise and the people they represent. Because political compromises rarely "split the difference" between what all parties hope to achieve, resistance may flow from the fear that a compromise will disproportionately benefit your political opponents, whom you are already disposed to distrust. Even when all parties stand to gain, such anticipatory resentment of unequal gain (or loss) can induce a blanket opposition to compromise.
Another source of general opposition to compromise - and the failure to recognize the costs of intransigence - is the perpetual hope that there is more to be gained (or less lost) in the future by avoiding compromise now. But notice: opponents of a compromise who use such a rationale are not opposing compromise in principle; they are introducing new, indirect, long-term projections of policy and strategy into the calculation of whether a compromise is truly preferable to the status quo. This perspective in turn opens the door for proponents of the compromise to introduce their own broader, long-term considerations. These may include the effects of the compromise on the possibility of future cooperation, as well as other consequences for the democratic process.

Those considerations point to the second important, but often neglected, value of compromise. Resistance to compromise undermines the mutual respect that is essential for a robust democratic process. Mutual respect expresses a constructive attitude toward one's political opponents and a willingness to engage in good faith with them. It is based on a principle of reciprocity, which is at the core of many different conceptions of democracy. ${ }^{19}$ Reciprocity seeks mutually acceptable ways not only of resolving disagreements but also of living with the disagreements that inevitably remain.

Mutual respect is consistent with many strategies for reaching agreement, including hard bargaining, provided it is done in good faith. But mutual respect excludes means that are intended to degrade, humiliate, or otherwise demean opponents who themselves demonstrate a willingness to negotiate in good faith (or would demonstrate it were they not being disrespected). Avoiding compromise by alienating your adversaries not only harms the citizens who stand to 
benefit from a particular compromise, but also diminishes the prospects for future compromises. When parties enter into negotiations in bad faith, deliberately misrepresent their opponents' positions, and refuse to cooperate even on matters on which they could find agreement, they undermine the relationships that are necessary to sustain any morally justifiable democracy under the modern conditions of deep and persistent disagreement.

$\mathrm{R}$ gnizing these two values of compromise - that it enables mutually beneficial improvements and promotes mutually respectful politics-may still not be sufficient to tip the balance in favor of a particular compromise. To understand fully the case for compromise, it is necessary to appreciate the fact that any specific compromise will by its nature be vulnerable to criticisms from all sides.

The philosopher George Santayana, a friend of compromise, captured the dual nature of the aversion to it: it is "odious to passionate natures because it seems a surrender, and to intellectual natures because it seems a confusion." 20 The sense of surrender stems from the fact that compromise demands the sacrifice of something valuable, and gives rise to suspicions that, but for the base motives of the other side, the agreement could have been better. The sense of confusion comes from the fact that compromises are combinations of often contradictory principles. Both of these reactions obscure the true value of compromise.

First, consider the surrender. Attitudes toward compromise are path-dependent: how a compromise is reached affects how it is evaluated. This is because a compromise distinctly manifests an opposition of wills. It is this opposition of wills that fuels the anticipatory resentment that your party will gain less, or lose more, than your opponent's. If you agree to a compromise, your assessment of the deal is substantially affected by whether you believe the other party bargained in good faith. Given the inevitable uncertainty of motives in legislative negotiations, and the near certainty that the motives are at least partly political, the circumstances are singularly ripe for distrust. Often even minor procedural manipulations (such as the reconciliation tactic used by the Democrats in passing the Affordable Care Act) may be perceived as signs of bad faith and give rise to suspicions that the process has been unfair. You may be willing to give up a principle if the process is fair, but if it is not, you understandably see an already bad bargain as even worse. The compromising adds insult to injury. Because the process of political negotiation is imperfect, it is tempting to fasten on the immediate insult and dismiss the prospective benefit of the agreement.

Then there is Santayana's point about confusion. A compromise is not designed to be coherent or principled in the way that laws ideally are. Even if we seek coherence in law, it is a mistake to think that it can be achieved in compromise. A classic compromise gives something to all parties, which means that the end result is almost always internally contradictory. The outcome will not be satisfying if judged from the perspective of any single principle or set of principles - whether yours or those of your opponents. You will reject nearly every possible compromise if you try to anticipate the outcome by testing it against a coherent theory of justice. By its nature, the outcome of a compromise will almost never satisfy a single principle, a set of principles, or a theory of justice. The compromise will not only fall short, as does most legislation, but it will include elements that are inconsistent with each other and with any single theory. 
Valuing

Compro-
mise

for the

Common
Compromise has its limits, but it is a mistake to try to stipulate categorically or in advance what they are. Consider the common precept that it is permissible to compromise interests but not principles. The problem is not that the distinction between interests and principles is fuzzy (it is), but rather that any such distinction - implying that interests may be compromised and principles should not - will disqualify too many potentially desirable compromises. Principles can be - and most often are - realized only partially. We implicitly accept this truth throughout our lives: even without compromising, we are not likely to realize absolutely our most prized political principles - liberty, opportunity, justice for all. Less lofty political principles, which often are no less passionately held - such as a commitment to lower taxation and entitlement spending, or to provide universal health care coverage and decrease its cost-even more clearly admit of gradations of realization. Compromises of principle and interest are neither morally nor practically distinct.

Furthermore, no one can fully anticipate what results the complex process of compromise can be expected to yield, especially in major legislative struggles. Achieving the best possible outcome will depend in no small measure on the nature of the negotiations and the evolving political context. Drawing a line in the sand - if more than a negotiating tactic - is a prescription for thwarting mutually beneficial progress before it can take form. And once agreed upon, compromises are easy targets for criticism simply because the apparent results often morally incoherent - are divorced from both the process and alternatives that were available at the time.

Instead of trying to find a formula for limiting compromise, we do better to locate its limits by identifying domains where it is less useful for the democratic process. The most salient domain, as we have indicated, is campaigning. A successful campaign strategy requires an uncompromising mindset. It favors candidates who stand firmly on their principles and condemn their opponents' positions at every turn. Candidates sometimes modify their positions to reach independents in general elections, but less than is usually assumed, and even a modest gesture toward the center is often suspect in the eyes of the candidate's base. The primary election effectively requires candidates to maximize their uncompromising positions to capture their partisan base, which will then assail primary winners if they diverge from their hard lines in the general election.

Tenaciously standing on principle, as the uncompromising mindset demands, is necessary for political mobilization. Candidates inspire supporters less effectively when they talk more about prudent compromises than about steadfast commitments. Their support and ultimately their success in the campaign depend on reaffirming their uncompromising commitment to core principles, and on distinguishing their positions sharply from those of their opponents.

Campaigning also requires mutual mistrust, the second element of the uncompromising mindset. Campaigns are competitive encounters, not cooperative enterprises. They are contests with zero-sum outcomes, not opportunities for win-win solutions. Mutual distrust is not only understandable but advisable.

But while the uncompromising mindset serves a useful democratic purpose in the domain of campaigns, it is detrimental when it dominates in the domain of governance. To govern, elected leaders have to adopt a compromising mindset. Rather than standing tenaciously on principle, they need to make concessions. 
Rather than mistrusting and trying to defeat their opponents at every turn, they have to respect their opponents enough to collaborate on legislation.

In the era of the permanent campaign, the division of labor between campaigning and governing has dissolved. ${ }^{21}$ Political leaders increasingly rely on political consultants, pollsters, and focus groups to formulate public policy. Interest groups and their lobbyists constantly remind politicians that what they do in office will affect whether they stay in officereminders that often come as offers not to be refused. Politicians spend more and more time between elections raising funds for their next campaigns. Journalists increasingly cover governing as if it were campaigning.

No one should suppose that we could return to a time when governing and campaigning stayed mostly in separate spheres, each minding its own business. The process then was in many respects less democratic, and no more edifying than ours today. But if we wish to improve the prospects of compromise, we must find ways to keep the pressures of campaigning from overwhelming the business of governing. We need to respect the value of not compromising in campaigns without letting it obscure the value of compromising in governance.

There is another, no less significant domain in which the value of compromise is limited. Uncompromising politics is valuable in social movements, political protests, demonstrations, and activist organizations, and their surrogates in government. As political theorists and political scientists have long recognized, contestation is at least as important as consensus in a democracy. ${ }^{22}$ Contentious politics is an essential part of the democratic process.

Among the most uncompromising activists in recent American political life have been the supporters of the Tea Party, the populist movement that began in Amy 2009 and rapidly grew in numbers and Gutmann \&Dennis influence. ${ }^{23}$ Promoting various conser- Thompson vative and libertarian causes, including smaller government, lower taxes, and reduced debt and budget deficits, the movement was credited with electing dozens of new state legislators and members of Congress.

Yet here, too, the uncompromising mindset has limits. When the Tea Party congressional representatives faced the choice between legislating or protesting, these limits became apparent. As some political scientists observed, "Tea Party activism is more likely to produce political theater among competing agitators than to foster reasoned compromise within the GOP or between Republicans and Democrats in Washington." This approach may help "keep base supporters attentive and angry," but it is not conducive to bringing about legislative change or to expanding the movement itself. ${ }^{24}$ This "just say no to compromise" approach also showed signs of frustrating even many Tea Party supporters. ${ }^{25}$

Compromise is essential for facilitating legislation to improve on the status quo and for cultivating the respect necessary for cooperation in democratic politics. It can in this way serve the common good without itself containing only common goods. Yet the political deck is stacked against compromise in many ways. The more the permanent campaign and its uncompromising mindset dominate the political landscape, the harder legislative agreements are to reach. When compromises are reached, they are, by their very nature, vulnerable. They rarely enjoy the luxury of resting on common ground; they too easily become casualties of confusion, dispatched for their incoherence, if they have not already become victims of death by distrust. 
Valuing We have suggested why the general Compro- value of compromise needs to be better
mise for the appreciated in governance. Politicians Common must confront the challenge of making Good specific compromises in order to address major public concerns and to overcome dysfunctional political gridlock. Because majorities of voters often favor compromise, some political scientists and reformers argue for the need to modify electoral institutions so as to give greater voice to majorities over intransigent minorities on both sides. Allowing independents to vote in all party primaries could help elect candidates with more compromising attitudes. Publicly financed campaigns could lessen the pressures of fundraising that both distract politicians from governing and influence the manner in which politicians govern. Rules that require members of Congress to spend more time working together in Washington, instead of rushing home to raise campaign money, could help.

These are all worthy reforms. We have elsewhere argued in favor of many of them. ${ }^{26}$ But any attempt to carry out such reforms comes with a catch-22. Institutional reforms themselves require a change in the mindsets of our political leaders: the reforms are impossible without compromise. Either legislators adopt a compromising attitude, in which case the reforms are not essential, or they do not adopt it, in which case they will not be able to agree on the reforms. There is no deus ex machina that will save democratic government from itself.

If legislators themselves do not recognize the value of compromise, then voters need to use elections to show that they do. Voters must choose representatives who care enough about governing to take the risks of compromising. This does not mean accepting candidates who abandon their principles or forgo partisanship. But it does mean choosing candidates who are able to set aside their uncompromising mindsets long enough to craft the compromises necessary to improve on the status quo and serve the common good.

\section{ENDNOTES}

* Contributor Biographies: AMY GUTMANN, a Fellow of the American Academy since 1997, is President of the University of Pennsylvania, where she is also the Christopher H. Browne Distinguished Professor of Political Science. Appointed in 2009 by President Obama, she chairs the Presidential Commission for the Study of Bioethical Issues. She was also the founding director of the University Center for Human Values at Princeton University. Her publications include The Spirit of Compromise: Why Governing Demands It and Campaigning Undermines It (with Dennis Thompson, 2012), Why Deliberative Democracy? (with Dennis Thompson, 2004), and Identity in Democracy (2003).

DENNIS THOMPSON, a Fellow of the American Academy since 1994, is the Alfred North Whitehead Professor of Political Philosophy in the Department of Government and Professor of Public Policy in the Kennedy School at Harvard University. He is also the founding director of the University Center for Ethics and the Professions (now the Edmond J. Safra Center for Ethics) at Harvard. His publications include The Spirit of Compromise: Why Governing Demands It and Campaigning Undermines It (with Amy Gutmann, 2012), Restoring Responsibility: Ethics in Government, Business, and Healthcare (2005), Why Deliberative Democracy? (with Amy Gutmann, 2004), and Just Elections: Creating a Fair Electoral Process in the United States (2002).

Authors' Note: This essay is drawn substantially from parts of our book, The Spirit of Compromise: Why Governing Demands It and Campaigning Undermines It (Princeton, N.J. : Princeton University Press, 2012). 
${ }^{1}$ John Rawls, A Theory of Justice, rev. ed. (Cambridge, Mass.: Harvard University Press, 1999), Amy $205-217$.

2 CBSNews, 60 Minutes, “Meet The Next House Speaker, Rep. John Boehner," December 12, \& Thompson 2010, http://www.cbsnews.com/stories/2010/12/o9/6ominutes/main7134156_page3.shtml ?tag=contentMain; contentBody.

3 Matt Viser, "For Romney, Bay State No Longer a Punch Line," The Boston Globe, October 27, 2011.

4 Nicolas Ballasy, "Reid: Senate will Stay in Session 'As Long As Necessary,"” Daily Caller, October 17, 2011, http://dailycaller.com/2011/10/17/reid-senate-will-stay-in-session-as -long-as-necessary-to-pass-35-billion-stimulus/.

5 John Rawls, Justice as Fairness (Cambridge, Mass.: Harvard University Press, 2003), $32-38$.

${ }^{6}$ Alan Simpson and Erskine Bowles, "Our Advice to the Debt Supercommittee: Go Big, Be Bold, Be Smart," The Washington Post, September 30, 2011.

7 Hugh Heclo, “Campaigning and Governing: A Conspectus," in The Permanent Campaign and Its Future, ed. Norman Ornstein and Thomas Mann (Washington, D.C.: American Enterprise Institute, 2000), 37.

8 Pew Research Center, "Broad Support for Political Compromise in Washington: But Many Are Hesitant to Yield on Contentious Issues" (Washington, D.C. : Pew Research Center, January 22, 2007), 12 .

9 Pew Research Center, "Few are Angry at Government, but Discontent Remains High" (Washington, D.C.: Pew Research Center, March 3, 2011), 1.

10 Pew Research Center, "Little Compromise on Compromising" (Washington, D.C.: Pew Research Center, September 20, 2010). Also see Pew Research Center, "Few are Angry at Government, but Discontent Remains High."

11 Pew Research Center, "Broad Support for Political Compromise in Washington," 14.

12 Frank Newport, "Americans Want New Debt Supercommittee to Compromise: Only Tea Party Supporters Take Hard-Line Stance," Gallup Poll report, August 10, 2011, http ://www .gallup.com/poll/148919/americans-new-debt-supercommittee-compromise.aspx.

13 Results are from a July 2011 nationwide CBS News poll reported by Kate Zernike, "That Monolithic Tea Party Just Wasn't There," The New York Times, August 2, 2011.

14 Edmund Burke, "On Conciliation with the Colonies," in Speeches and Letters on American Affairs (London: Dent, 1908), $130-131$.

15 Edmund Burke, "Speech to the Electors of Bristol," November 3, 1774, in The Founders' Constitution, vol. 1, ed. Philip B. Kurland and Ralph Lerner (Chicago: University of Chicago Press, 1987), $391-392$.

16 Dennis F. Thompson, "Mill in Parliament: When Should a Philosopher Compromise?” in J. S. Mill's Political Thought, ed. Nadia Urbinati and Alex Zakaras (Cambridge: Cambridge University Press, 2007), 166 - 199.

17 Pew Research Center, "Broad Support for Political Compromise in Washington," 15.

${ }^{18}$ David Brady and Morris Fiorina, "Congress in the Era of the Permanent Campaign," in The Permanent Campaign and Its Future, ed. Ornstein and Mann, 154-155.

19 Mutual respect and reciprocity play a prominent role in theories of deliberative democracy: see Amy Gutmann and Dennis Thompson, Why Deliberative Democracy? (Princeton, N.J.: Princeton University Press, 2004), 95-124, 151-156; and Amy Gutmann and Dennis Thompson, Democracy and Disagreement (Cambridge, Mass.: Harvard University Press, 1996), 52-55, 79-91. Many other theorists also emphasize the importance of the principle of reciprocity (and by implication the value of mutual respect). See, for example, Corey Brettschneider, Democratic Rights: The Substance of Self-Government (Princeton, N.J. : Princeton 
Valuing University Press, 2010), 34-37; Ronald Dworkin, Is Democracy Possible Here? (Princeton, Compro- $\quad$ N.J.: Princeton University Press, 2008), 5, 64, 112, $132-133$.

mise
for the ${ }^{20}$ George Santayana, Soliloquies in England and Later Soliloquies (New York: Charles Scribner's Common Sons, 1923), 83; emphasis added.

Good

${ }^{21}$ For a sharp contrast between the concepts of campaigning and governing, see Heclo, "Campaigning and Governing," in The Permanent Campaign and Its Future, ed. Ornstein and Mann, 4-15.

22 See, for example, Charles Tilly and Sidney Tarrow, Contentious Politics (Boulder, Colo. : Paradigm Publishers, 2006). The classic statement of the value of contention is John Stuart Mill's On Liberty; see John Stuart Mill, Collected Works, vol. 18, Essays on Politics and Society, ed. J. M. Robson (London: Routledge and Kegan Paul, 1977).

23 Kate Zernike, Boiling Mad: Inside Tea Party America (New York: Times Books, 2010); Jill Lepore, The Whites of Their Eyes: The Tea Party's Revolution and the Battle over American History (Princeton, N.J.: Princeton University Press, 2010); and Theda Skocpol and Vanessa Williamson, The Tea Party and the Remaking of Republican Conservatism (New York: Oxford University Press, 2012).

24 Skocpol and Williamson, The Tea Party and the Remaking of Republican Conservatism, 36 - 37.

25 Zernike, “That Monolithic Tea Party Just Wasn’t There.”

26 Amy Gutmann and Dennis Thompson, The Spirit of Compromise: Why Governing Demands It and Campaigning Undermines It (Princeton, N.J. : Princeton University Press, 2012), 168 - 204. 